\title{
THE GCC DIPLOMATIC RIFT AND ITS REVERBERATIONS UPON ROMANIAN PRESENCE IN THE REGION
}

\author{
I. F. MAGLAS
}

\author{
Maglas Ioana Florina \\ Faculty of History and Philosophy, Department of International Relations \\ Babeș-Bolyai University, Cluj-Napoca, Romania \\ *Correspondence: Maglas Ioana Florina, Doctoral School of International Relations and \\ Security Studies, 7-9 Universitatii St., Cluj-Napoca 400084, Romania \\ E-mail:MAGLAS.Ioana-Florina@ubbonline.ubbcluj.ro.
}

\begin{abstract}
By virtue of their economic influence, the Arab States of the Gulf are highly interlinked within the global community. Dimensions of globalization (such as outward looking focus on international trade, openness, growing business opportunities and investment) are shifting their interests to a broad spectrum of partners leading to increased connectivity platforms and links. Apparent deteriorating ties seriously undermines relations among $G C C^{l}$ players and adversely affects its functioning. Current dispute, centered on allegations about Qatar's foreign policy, caused much consternation, in fact, unequivocally conflicted with the interests of other members and escalated tensions. A scheme of prolonged economic isolation for the Gulf state of Qatar presents challenges and opportunities for Romania (particularly in food security initiatives in Qatar), however, in light of inter-regional realignments, a united GCC stance must consequently prevail to promote stability and reinforce its status of regional power in the Arab World, that would develop and maintain a strong bilateral relationship between Romania and the GCC.
\end{abstract}

KEYWORDS: Gulf Cooperation Council, diplomatic crisis, trade, Romanian entities

\section{INTRODUCTION}

The official inauguration of the Cooperation Council for the Arab States of the Gulf referred to as the Gulf Cooperation Council (GCC) ${ }^{2}$ took place in May 1981 in the midst of Iran-Iraq conflict with the Charter signed on the $25^{\text {th }}$ of May in Abu Dhabi City, United Arab Emirates. ${ }^{3}$ In some ways the GCC mirrors the European Union. Essentially there are two core intergovernmental bodies, a Supreme Council (consists of the six heads of the member states and summoned once per year) and a Ministerial Council (comprised of six foreign ministers which gather four times per year). ${ }^{4}$

Qatar peninsula is about 11,586 sq. $\mathrm{km}$ and it connects to the mainland with eastern border of Saudi Arabia. ${ }^{5}$ Before falling under the control of the al Thani family in the midnineteenth century, the present-day leadership of Bahrain (al Khalifa family) dominated parts

\footnotetext{
${ }^{1}$ (Gulf Cooperation Council (GCC) is a political and economic union currently consisting of Bahrain, Kuwait, Qatar, Oman, Saudi Arabia and the United Arab Emirates)

${ }^{2}$ The Cooperation Council for the Arab States of the Gulf Secretariat General, 'The Charter of the GCC' (2016), Article1, available at: http://www.gcc-sg.org/en-us/AboutGCC/Pages/Primarylaw.aspx (accessed on $7^{\text {th }}$ February 2017).

${ }^{3}$ Riccardo Dugulin, 'A Neighborhood Policy for the Gulf Cooperation Council' (Gulf Papers Series,Gulf Research Center, United Arab Emirates, 2010), p. 9.

${ }^{4}$ The Cooperation Council for the Arab States of the Gulf Secretariat General, Organizational Structure, 2016, available at: http://www.gcc-sg.org/en-us/AboutGCC/Pages/OrganizationalStructure.aspx , (accessed on 12 $2^{\text {th }}$ July 2017).

${ }^{5}$ Central Intelligence Agency (CIA), 'World Fact Book: Middle East: Qatar' available at:https://www.cia.gov/library/publications/the-world-factbook/geos/qa.html (accessed on 10 ${ }^{\text {th }}$ July, 2017).
} 


\section{Ioana Florina MAGLAS}

of the Qatari peninsula. Both countries reasserted and claimed authority of the Hawar Islands and were confined under the territorial dispute until 2001 when the issue was settled and internationally recognized at the International Court of Justice. ${ }^{6}$ The longstanding border dispute between Saudi and Qatar which resulted in the 1992 clash preoccupied the ruling families in both countries for decades. ${ }^{7}$ Qatar's rise to global prominence coincided with a new generation of leadership which embraced economic openness, astute strategy design and accelerated the development of its liquefied natural-gas infrastructure and long-term energy agreements with emerging economies worldwide. ${ }^{8}$ The Qatari foreign policy and diplomatic moves with the new rule of Shaikh Tamim bin Hamad al Thani from June $2013^{9}$ involved the desire of consolidating national interests however not necessarily in coordination or mutual agreement or policy consistent with the other GCC member states. ${ }^{10}$ There are a number of factors from local, regional and international that appears to have contribute to the shift in Qatar's more independent position. Viewed through a lens of predominant realist approach 'the realists assume that the real issues of international politics can be understood by the rational analysis of competing interests defined in terms of power'. ${ }^{11}$ At the same time Qatar strengthen its alliance with the US and the partnership with the GCC members however, it is also on good terms with regional rivals such as Iran to the detriment of its diplomatic relations with its neighbours. ${ }^{12}$

The Gulf monarchies were unable to prevent the crisis or the conflict scenario from emerging and the 37 years old alliance was impacted to the extent that it caused rupture of diplomatic ties between United Arab Emirates (UAE), Saudi Arabia (KSA), Bahrain, Egypt and Qatar on Monday $5^{\text {th }}$ of June 2017. Under the move, Saudi Arabia closed its borders with Qatar and blocked access and contacts (land, sea and air) for respective Qatar routes. ${ }^{13} \mathrm{With}$ the exception of Oman and Kuwait, other countries joined the Saudi's positions against Qatar's open-door policy towards political actors in the region and the rift appeared to be widening (Yemen, Egypt, Libya, Mauritius, Maldives, Senegal, United Nations of Comoros and Mauritania also cut diplomatic ties with Qatar while Jordan, Chad, Djibouti, Niger downgraded diplomatic ties). The two remaining GCC member states, Kuwait and Oman, less interventionist, have not announced their stance on the rift and have been trying to mediate between all parties. The collapse in the relation with the GCC also resulted in the formation of the Saudi-UAE committee announced at the GCC summit in Kuwait City attempting to represent an alternative vis-à-vis the GCC bloc. ${ }^{14}$

According to public debate, the Qatar's crisis and country's distinctive approach to regional affairs has several components that grown intertwined as Qatar became more independent in regional and international relations. Saudi Arabia, United Arab Emirates, Bahrain and Egypt charged Doha of extending financial support and dedicating resources for

\footnotetext{
${ }^{6}$ Krista E. Wiegand, 'Bahrain, Qatar, and the Hawar Islands: Resolution of a Gulf Territorial Dispute' (2012) Middle East Journal 66, pp. 79-96.

${ }^{7}$ The New York Times, 'Qatar Says Saudis Seized Its Border Post', (News Article, $2^{\text {nd }}$ October, 1992) available at: http://www.nytimes.com/1992/10/02/world/qatar-says-saudis-seized-its-border-post.html, (accessed on $12^{\text {th }}$ July 2017).

${ }^{8}$ LinaKhatib, 'Qatar's foreign policy: The limits of pragmatism', (2013) International Affairs 89, pp. 417-413.

${ }^{9}$ Ian Black, 'Qatar's emir Sheikh Haman to had power to son, crown prince Tamim' (The Guardian, 24 ${ }^{\text {th }}$ June, 2013) available at: https://www.theguardian.com/world/2013/jun/24/qatar-emir-steps-down-son-tamim (accessed on $6^{\text {th }}$ December 2017).

${ }^{10}$ LinaKhatib, 'Qatar's foreign policy: The limits of pragmatism', (2013) International Affairs 89, pp. 417-413.

${ }^{11}$ Jack Donnelly, Realism in International Relations (Cambridge University Press, United Kingdom, 2000 ) p. 7.

${ }^{12}$ LinaKhatib, 'Qatar's foreign policy: The limits of pragmatism', (2013) International Affairs 89, p. 418.

${ }^{13}$ Patrick Wintour, 'Gulf plunged into diplomatic crisis as countries cut ties with Qatar' (News Article, The Guardian, $5^{\text {th }}$ June, 2017) available at: https://www.theguardian.com/world/2017/jun/05/saudi-arabia-andbahrain-break-diplomatic-ties-with-qatar-over-terrorism(accessed on $7^{\text {th }}$ June 2017).

${ }^{14}$ Patrick Wintour, 'UAE announces new Saudi Alliance that could reshape Gulf relations' (The Guardian, $5^{\text {th }}$ December, 2017) available at: https://www.theguardian.com/world/2017/dec/05/uae-saudi-arabia-alliance-gulfrelations-gcc (accessed on $7^{\text {th }}$ December 2017).
} 


\section{THE GCC DIPLOMATIC RIFT AND ITS REVERBERATIONS UPON ROMANIAN PRESENCE IN THE REGION}

high profile Islamist groups that emerged to disrupt the balance in the region and, Al Jazeera, the Doha based broadcaster was being used as a platform and instrument for such groups with a far reaching, impact given its new dynamic of engagement. ${ }^{15}$ There have been minor sporadic diplomatic breakdowns between the countries, but another worrisome crisis broke out in 2014. Once again old emerging issues and past differences have blown up over border demarcation and the four capitals escalated a trend of bilateral disengagement and judged that the leadership in Doha has repeatedly failed to meet its promises and was not in full compliance with the agreements and written obligations to the GCC signed in $2014 .^{16}$

Subsequent to withdrawing diplomatic ties, a series of measures against Qatar severely impacted the movement of people with a number of airlines announcing flight cancellations to/from Doha. UAE based airlines Etihad Airways, Emirates, AirArabia, Flydubai andRoyal Jet suspended service to of Qatar effective June $6^{\text {th }}$ 2017. Saudi Arabia, UAE and Bahrain took measures against Qatar by issuing a ban for nationals to travel the country, and taking the decision to expel Qatari nationals. Subsequently, Qatar Airways, the state-owned flag carrier of the state Qatar suspended all flights to Saudi Arabia, UAE, Bahrain and Egypt. ${ }^{17}$ Banning of Qatar Airway flights from UAE, Saudi and Bahrain airspace resulted in significant delays and flight cancellations. The flight cancellations primarily impacted those who fly to and from the UAE and Qatar regularly due to work commitments increasing duration and cost given that longer routes through Kuwait and Oman had to be considered. The restriction of movement had serious implications for commercial entities in relation to set-up and servicing the rest of the Gulf monarchies as most of the financial institutions, consultancies and food consolidators historically set up in the UAE as a gateway due to the developed infrastructure and access. Qatar's has managed to increase its international prestige and casted an image of beneficial business climate. Large corporations are adapting to the change by setting up a presence in Doha, however small and medium-sized businesses are finding hard to maintain commercial relations with Qatar while the GCC dispute remains due to limited budgets and requirements to deliver projects on schedule.

Qatar is the third largest projects' market (USD\$228.4 Billion planned or under construction $)^{18}$ in the GCC after Kingdom of Saudi Arabia and the United Arab Emirates, with project companies already feeling the effect of slowdown in activity in 2016/2017. Imposing economic sanctions and closing vital land border with Saudi Arabia will affect Qatar's imports including food. The Gulf monarchy is heavily dependent on food imports and construction materials leading to disruptions that may significantly affect the country. ${ }^{19}$ Since the crisis began Qatar continued to prioritize food security strategies and invested in food security facilities and warehouses making it better positioned to serve its domestic needs. ${ }^{20}$

\footnotetext{
15 Patrick Wintour, 'Qatar diplomatic crisis - what you need to know' (The Guardian, $5^{\text {th }}$ June, 2017) available at: https://www.theguardian.com/world/2017/jun/05/qatar-diplomatic-crisis-what-you-need-to-know (accessed on $7^{\text {th }}$ June 2017).

${ }^{16}$ The National, 'Revealed: the secret pledges Qatar made — and then broke. Formerly secret documents show commitments Doha made to fellow Arab countries in 2013 and 2014' (News Article, 11 ${ }^{\text {th }}$ July 2017) available at:https://www.thenational.ae/world/gcc/revealed-the-secret-pledges-qatar-made-and-then-broke-1.484155 (accessed on $12^{\text {th }}$ July 2017).

17 Paul Crompton, 'How the Qatari crisis affects you', (Gulf News, $5^{\text {th }}$ June, 2017) available at: http://gulfnews.com/news/uae/general/how-the-qatari-crisis-affects-you-1.2038738 (accessed on $7^{\text {th }}$ June 2017). ${ }^{18}$ Ventures Onsite, 'Qatar Constructions Industry 2017' (Report, May 2017) available at: http://www.projectqatar.com/pdf/Qatar\%20Construction\%202017.pdf(accessed on $25^{\text {th }}$ June 2017).

19 Adams Taylor, 'Qatar could face a food crisis in spat with Arab neighbors' (The Washington Post, $5^{\text {th }}$ June, 2017) available at: https://www.washingtonpost.com/news/worldviews/wp/2017/06/05/qatar-could-face-a-foodcrisis-in-spat-with-arab-neighbors/?utm_term=.b5b8a644b52b (accessed on 10 ${ }^{\text {th }}$ June 2017).

${ }^{20}$ IrfanBukhari, 'QR 1.6bn food security project launched' (The Peninsula, 17 $7^{\text {th }}$ July 2017) available at: https://www.thepeninsulaqatar.com/article/17/07/2017/QR1.6bn-food-security-project-launched accessed on $2^{\text {nd }}$ December 2017.
} 


\section{Ioana Florina MAGLAS}

Qatar imports $90 \%$ of its food supplies ${ }^{21}$ and $40 \%$ enters the country from Abu Samra, the only Saudi - Qatari land border crossing. In the short to medium term, Qatar will become reliant on air and sea freight with suppliers already connected through Qatar Airways.Turkey, Morocco, Lebanon and Iran already attempted to address shortages in water, meat, sugar and vegetables supplies and sent fresh produce to Qatar via air freight. ${ }^{22}$ The rerouting of trade will raise the cost of imports and pass-through to consumer inflation and prompts entitiesdoing business with Qatar to essentially plan for operational disruptions and seek legal advice to assess existing contractual terms. The impact caused by the disruption to the flow of goods and people by air, land, or sea, could trigger severe implications causing rapid economic dislocation and leading to social or political unrest.

Romanians in the region are no longer able to travel directly to Qatar from the UAE, Saudi Arabia and Bahrain. Romanians in managerial positions with regional responsibilities will find it difficult to meet with potential leads and achieve relevant sales and engagement targets due to this disruption. It is estimated that the current travel restrictions will remain in place for the coming month impacting on Qatar tourism, industry, aviation - all relevant for Romanian professionals doing work in the region. In addition, this instability has a tendency to reduce the influx of Romanians to the region due to media coverage that may place inaccurate information and leads to departures as a result of perceived threats.

By all accounts, Qatar remains confident in their economic prospects and signed a transportation agreement and a bilateral deal in the field of engineering with Turkey and Iran to speed up the movement and exchanges of goods and to ease economic pressure by the GCC states. ${ }^{23}$ Despite the fact that Qatar has ensured uninterrupted food supplies we must not overlook the disturbing tendency and adverse impacts of the diplomatic crisis and the related consequences for food security, the vast bulk of its food is imported and the sanctions have halted transport of foodstuff and disrupted shipping routes.

This crisis presents challenges and opportunities for Romanian entities. The main challenge revolves around logistical requirements, transport, shipping and freight. Romanian exporters will face increased costs for exporting their products to Qatar due to increase time of shipping through Oman and Kuwait as most of the large shipping lines only ship to United Arab Emirates (Jabel Ali). Smaller vessels depart the UAE loaded with products to other GCC countries. However, the crisis also leads to opportunities for Romanian exporters especially in the food and agriculture sector given Qatar's high level of food import dependency therefore Romanian food exporters may provide a direct channel for the Qatari market in areas such as fresh food, meat, proteins and grains.

Bilateral trade between Romania and Qatar outlined an ascending trend with a relative dominance of food, furniture, clothing, chemicals, materials, plastic products, machinery, industrial equipment and imports from Qatar include oil and petrochemicals. Romanian Ministry of Foreign Affairs revealed a total trade figure between the two nations of \$US 56.88 million for 2015. ${ }^{24}$ In additions, the existence of eighteen bilateral agreements between Romania and Qatar provide the required foundation to consolidate and further cement the bilateral relationship. ${ }^{25}$

\footnotetext{
${ }^{21}$ Oxford Business Group, 'Report: Qatar 2015' (Report, 2015).

22 Jason Neely and Mark Potter, 'Iran flies food to Qatar amid concerns of shortages' (Reuters, $11^{\text {th }}$ June, 2017) available at: https://www.reuters.com/article/us-gulf-qatar-iran-idUSKBN1920EG?il=0 (accessed on $14^{\text {th }}$ June 2017).

${ }^{23}$ Jim Carey, 'Iran, Turkey, and Qatar sign Major Transportation Deal to Boost Trade' (Geopolitics Alert, 26 ${ }^{\text {th }}$ November 2017) available at: http://geopoliticsalert.com/iran-turkey-qatar-transportation-deal accessed on $4^{\text {th }}$ December 2017.

${ }^{24}$ Romanian Ministry of Foreign Affairs, Bilateral Relations with the State of Qatar (Department of Middle East and North Africa, Bucharest, February 2016) available at: https://www.mae.ro/bilateral-relations/1785\#782 (accessed December $\left.4^{\text {th }}, 2017\right)$.

${ }^{25}$ Ibidem
} 


\section{THE GCC DIPLOMATIC RIFT AND ITS REVERBERATIONS UPON ROMANIAN PRESENCE IN THE REGION}

A potential challenge faced by all entities in the region and exporters may be related to the payment for relevant projects in Qatar and the impact of potential financial sanctions imposed by the GCC in dealing with Qatar. In addition to reduced regional trade, Saudi Arabia's central bank advised banks in the kingdom to hold off on deals with Qatari banks. Similarly, UAE, Bahrain and Egypt's local banks received instructions to limit transactions, delay business with Doha and report their exposure to Qatari banks. Qatar has enough financial power to protect its banks and provide liquidity given its massive SWF estimated at US $\$ 320$ billion $^{26}$ however, given Qatar's integration with regional counterparts combined with lower confidence levels, foreign business links may be intensely impacted. ${ }^{27}$ Romanian entities planning for business and operational disruptions will incur additional costs that were not originally stipulated in contracts and business agreements. The challenge for Romania is to maintain a competitive edge whilst factoring risk management and costs as a result of the blockade.

Kuwait has played an unmatchable big brother role in restoring balance and narrowing the gaps between the crisis-affected countries. In past disputes which engulfed Qatar, Kuwait was recognised as virtually the key contributor, a fundamental intermediary and played essential roles to assuage consequences of dissention. ${ }^{28}$ Its leadership facilitated dialog and conciliation and pursued mitigation in a way that resonated with all sides. The present predicament is still in its early stages however, as in previous times, the success of mediation is yet to be seen given that these countries rejected Qatar's response to their demands as of $12^{\text {th }}$ July 2017. A negotiation route out of the rift will work if it considers diverging interests of the concerned parties and resonates with local cultural nuances and norms.

In the Middle East North Africa region, the GCC bloc emerged as an organization with effective dispute resolution functions, a competent force from a regional security role and the main forum for the conduct of collective diplomacy by its member states thus, on the political front that provided Romania with a clear and well-defined engagement plan across the GCC region. The diplomatic crisis will open new avenues for foreign players in Europe and the Middle East to be involved in the political, economic and social streams in the Gulf monarchies. In long term, however, the uncertainty and the shifting of allegiances in some instances are bound to create additional political tensions, all of this, in turn leaves little room for Romania to manage and consolidate the key relationships in the region it wishes to pursue.

\section{CONCLUSION}

The current GCC diplomatic split is damaging for all parties involved and in particular for foreign countries like Romania, trying to navigate the political and economic sphere in the GCC. The estimation of the economic costs (around \$US 1 Billion including loss of projects for companies and investments) is an essential first step for reversing the damage caused by the recent dispute between Qatar and the other Arab state actors. Gulf-based power structures are embedded with glaring manifestations of tribalism, rigid cultural conceptions and pride. Besides, their identities are defined by inherent patrilineal networks, the role of Islam,

26 Sovereign Wealth Fund Institute, Sovereign Wealth Fund Rankings, available at: http://www.swfinstitute.org/sovereign-wealth-fund-rankings/ (accessed on 12 ${ }^{\text {th }}$ July, 2017).

27 Tom Arnold and SaeedAzhar, 'UAE blacklist may squeeze liquidity of Qatari banks. The move followed the isolation of Qatar by the four states' (News Article, Business Standard, 10 ${ }^{\text {th }}$ June, 2017) available at: http://www.business-standard.com/article/international/uae-blacklist-may-squeeze-liquidity-of-qatari-banks117061000737 1.html (accessed on 11 $1^{\text {th }}$ July, 2017).

${ }^{28}$ Naser Al Wasmi, 'Kuwait faces tough test as it struggles to resolve Qatar crisis. Country has become the peacemaker of choice in the fractious dispute between Doha and its neighbours', (The National, $5^{\text {th }}$ July 2017) available at: https://www.thenational.ae/world/kuwait-faces-tough-test-as-it-struggles-to-resolve-qatar-crisis1.91724 (accessed on $5^{\text {th }}$ July, 2017). 


\section{Ioana Florina MAGLAS}

increasingly diverse domestic politics and conflicting foreign policy approaches which enabled different national level politics. Hence, only in line with sufficient understanding of this pertinent background, the architecture of international relations and the compelling processes at work in the GCC states a more broad-based approach can be contemplated and truly increase connectivity platforms and links.

Romania's ability and willingness to engage directly with Qatar as evidenced by a number of high level visits, bilateral agreements and trade exchanges appears to remain solid and may provide further opportunities and pave the way for new Romanian entities and presence in the region. The emerging trend in engagement between Qatar and Romania and interest in the region favors the consolidations of bilateral ties. Expanding Romania Qatar relations may also signal stronger economic and investment gains. In turn, Romania has to recognize that engagement in the Gulf is a multi-dimensional phenomenon and must balance its relationships and commercial interests for Romanian entities in United Arab Emirates and Saudi Arabia. High level visits across the region by Romanian officials must continue with all relevant stakeholders because despite the diplomatic rift, the GCC remains a substantial integrated bloc with a shared history of achievements and challenges that are usually overcome.

\section{BIBLIOGRAPHY}

1. Al Wasmi, Naser, 'Kuwait faces tough test as it struggles to resolve Qatar crisis. Country has become the peacemaker of choice in the fractious dispute between Doha and its neighbours', (The National, 5th July 2017);

2. Arnold, Tom and SaeedAzhar, 'UAE blacklist may squeeze liquidity of Qatari banks. The move followed the isolation of Qatar by the four states' (Business Standard, $10^{\text {th }}$ June, 2017);

3. Black, Ian, 'Qatar's emir Sheikh Haman to had power to son, crown prince Tamim' (The Guardian, 24 ${ }^{\text {th }}$ June, 2013);

4. Blanchard, Christopher M. 'Qatar: background and US relations' (Congressional Research Service paper, $4^{\text {th }}$ November 2014);

5. IrfanBukhari, 'QR 1.6bn food security project launched' (The Peninsula, $17^{\text {th }}$ July 2017);

6. Carey, Jim, 'Iran, Turkey, and Qatar sign Major Transportation Deal to Boost Trade' (Geopolitics Alert, 26 ${ }^{\text {th }}$ November 2017);

7. Central Intelligence Agency (CIA), 'World Fact Book Middle East: Qatar' (Publications, 2016);

8. Crompton, Paul 'How the Qatari crisis affects you', (Gulf News, $5^{\text {th }}$ June, 2017);

9. Dugulin, Riccardo 'A Neighborhood Policy for the Gulf Cooperation Council' (Gulf Papers Series, Gulf Research Center, United Arab Emirates, 2010), p. 9;

10. Khatib, Lina 'Qatar's foreign policy: The limits of pragmatism', (2013) 89 International Affairs 417;

11. Neely, Jason and Mark Potter, 'Iran flies food to Qatar amid concerns of shortages' (Reuters, $11^{\text {th }}$ June, 2017);

12. Oxford Business Group, 'Report: Qatar 2015' (Report, 2015);

13. Romanian Ministry of Foreign Affairs, Bilateral Relations with the State of Qatar (Department of Middle East and North Africa, Bucharest, February 2016);

14. Sovereign Wealth Fund Institute, Sovereign Wealth Fund Rankings (Publications, 2017);

15. Taylor, Adams 'Qatar could face a food crisis in spat with Arab neighbors' (The Washington Post, $5^{\text {th }}$ June, 2017);

16. The Cooperation Council for the Arab States of the Gulf Secretariat General, 'Charter of the GCC' (2016); 
17. The Cooperation Council for the Arab States of the Gulf Secretariat General, 'Organizational Structure' (2016);

18. The National, 'Revealed: the secret pledges Qatar made - and then broke. Formerly secret documents show commitments Doha made to fellow Arab countries in 2013 and 2014' (News Article, $11^{\text {th }}$ July 2017);

19. The New York Times, 'Qatar Says Saudis Seized Its Border Post', (News Article, $2^{\text {nd }}$ October, 1992);

20. Ventures Onsite, 'Qatar Constructions Industry 2017' (Report, May 2017);

21. Wiegand, Krista E., 'Bahrain, Qatar, and the Hawar Islands: Resolution of a Gulf Territorial Dispute' (2012) 66 Middle East Journal 79;

22. Wintour, Patrick 'Gulf plunged into diplomatic crisis as countries cut ties with Qatar' (The Guardian, $5^{\text {th }}$ June, 2017);

23. Wintour, Patrick 'Qatar diplomatic crisis - what you need to know' (The Guardian, $5^{\text {th }}$ June, 2017);

24. Wintour, Patrick 'UAE announces new Saudi Alliance that could reshape Gulf relations' (The Guardian, $5^{\text {th }}$ December, 2017). 